Relations industrielles

Industrial Relations

\title{
Minchin, Timothy J., What Do We Need A Union For? The TWUA
}

in the South, 1945-1955

\section{Bryan D. Palmer}

Volume 52, numéro 4, 1997

URI : https://id.erudit.org/iderudit/051210ar

DOI : https://doi.org/10.7202/051210ar

Aller au sommaire du numéro

Éditeur(s)

Département des relations industrielles de l'Université Laval

ISSN

0034-379X (imprimé)

1703-8138 (numérique)

Découvrir la revue

Citer ce compte rendu

Palmer, B. D. (1997). Compte rendu de [Minchin, Timothy J., What Do We Need A Union For? The TWUA in the South, 1945-1955]. Relations industrielles /

Industrial Relations, 52(4), 892-894. https://doi.org/10.7202/051210ar

Tous droits réservés @ C Département des relations industrielles de l'Universite Laval, 1997
Ce document est protégé par la loi sur le droit d'auteur. L’utilisation des services d'Érudit (y compris la reproduction) est assujettie à sa politique d'utilisation que vous pouvez consulter en ligne.

https://apropos.erudit.org/fr/usagers/politique-dutilisation/ 
This is a prelude to the analysis, in Chapter 4 , of labour relations and politics in the 1990s. The account includes the role of technology, de-industrialization, changes in gender in the workplace and the rise in the number of "foreign" workers. Other issues addressed encompass the decline of Keynesianism, the end of dictatorship and the demise of communism in Latin Europe.

In Chapter 5, the importance of multiemployer bargaining in European labour relations is addressed and it is linked with models of conflict in various parts of Europe. More specifically, issues associated with the public sector (and its relative decline) are also examined. The importance of worker participation (and particularly of works councils) to European industrial relations are addressed in Chapter 6 . Again this is a major unifying theme of much of European labour relations that makes European models so different from those of North America and Japan.

Modern developments in Europe are then highlighted in the ensuing chapters. Above all, the movement from sector bargaining to enterprise diversity accompanying the decentralization of collective bargaining is developed as a key recent trend. Labour conditions in Europe (wages, working time, health and safety, social insurance, and employment and employment protection) are examined in Chapter 8. Moreover, the fundamental issues raised for European labour relations from the European Union are featured in Chapter 9. And, in this respect,
Slomp (p. 126) concludes that: "For a long time to come, Europe will continue to be a patchwork of nation states with national systems of labor relations. Only with great difficulty can they be grouped together into a British, a Germanic and a Latin model in order to show common European trends as well as major European cleavages."

Finally, there are two somewhat idiosyncratic chapters. First of all pairs of nations (Denmark and Norway, Belgium and Holland, Austria and Switzerland, Portugal and Spain and Hungary and Poland) are contrasted. And last of all there is "a summary in American terms."

In evaluation, this study can be recommended as an introductory text. To be sure, there is little here of a theoretical nature (e.g., on forces for convergence or divergence). The structure of the book could have been tighter. The groups of countries identified are somewhat difficult to defend (e.g., Ireland as opposed to Britain has largely continued with tripartism). Some of the major worldwide developments which have so much affected industrial relations (such as the rise of the multinationals) receive only a cursory examination. And, as indicated earlier, the last two chapters fit uneasily into the structure of the overall book. But it is interesting and, above all, the historical detail helps to make the book a valuable one.

MICHAEL POOLE Cardiff Business School, UK

What Do We Need A Union For? The TWUA in the South, 1945-1955

by Timothy J. MINCHIN, London and Chapel Hill : University of South Carolina Press, 1997, 285 p., ISBN 0-8078-4625-2

C. Vann Woodward once noted that the history of the American South is one of benign neglect. Professions of nationalism from "new south" historians have fed into tacit assumptions that the mean- ing of the South can be adequately covered by integrating its unique history into the general contours of the national story, with a cursory reference to the region's perverse sectionalism, composed of an 
evolutionary progress blemished by the presence of "poor whites" and "the race problem." When Woodward wrote his Origins of the New South in 1951 the region, long central to the ambiguities and contradictions at the heart of the meaning of the United States, was on the threshold of vast changes. Not the least of these were issues associated with the relations of labour and capital, in which southern textiles and the industry's millworker communities figured pivotally.

Timothy J. Minchin takes a ten-year period straddling this mid-century fulcrum of social transformation and explores the history of the Textile Workers Union of America (TWUA). It was a pivotal decade in which mass production unionism in the South tested its potential strength and came up short, losing a decisive regional battle in a bitterly contested, often violent, 1951 General Strike. Capital's victory, an opening shot of strength fired against the post-World War II upsurge of American labour, prefaced the more general set of defeats that would be visited upon the collective head of the United States working class in the latter half of the twentieth century. If the Congress of Industrial Organization-led Operative Dixie was a mixed success that nevertheless failed to win workers their broadest demands and aspirations, the textile workers fared the worst, and the back of their organized presence in the South was broken.

What Do We Need a Union For? addresses this defeat, but refuses to follow the path of easy interpretation provided by conventional wisdom. Minchin challenges the stereotypical construction of the mill worker as passive and hostile to unionism, developing a more subtle and sustained portrait of textile workers as an embattled contingent capable of militancy and strong commitments to democratizing the workplace and securing economic rights. Against the one-dimensional caricature of the white worker as southern "cracker", moved most passionately by a virulent racism, Minchin explores the racial dynamics of class formation and the ways in which black and white workers negotiated the privilege and subordination of skin colour against the increasingly material pressures of class place. Race difference, expressed in segregated locals, did not always undercut common class interests and could, in certain historical conjunctures, secure black Americans a place of significance, despite their minority status in the mills and their relegation to the worst of job sites, in union politics and class struggles: in the 1951 strike in the huge Dan River Mills textile complex of Danville, Virginia, explored in an impressively researched chapter in Minchin's book, blacks were the strongest of union supporters. With defeat staring the union menacingly in the face, barely $35 \%$ of Danville's white workers continued to support the strike, but $95 \%$ of blacks remained steadfast, refusing to cross picket lines and return to work. Women, too, were defiantly militant; comprising $50 \%$ of the workforce of the mills, they bucked the labels of ladyhood to taunt scabs, lead picket lines, and lay down in front of trucks that threatened to enter the plants.

If Minchin challenges convention in his detailed reconstruction of textile workers and their battles with bosses, he also refuses easy answers in terms of what constitutes victory and defeat. The strike of 1951 was indeed a crippling blow to unionism in the South, and set workers back decisively ; Minchin's sober assessment of this difficult defeat avoids sidestepping the harsh reality of that moment of working-class loss. Yet he never loses sight of the extent to which textile unionism in the South advanced the cause of labour: it was unionism's presence that kept the wage rate in non-union mills high (which, ironically, undercut textile unionism in the long run), just as it was labour organization that brought whites and blacks, men and women, and the children of all of these Southern people, out of the incarcerating peonage, 
debilitating poverty, and cultural malaise of their past. Material destitution and its suffocating of any semblance of democratic involvement in life on and off the job was, whatever the ultimate defeat of textile unionism, overcome by trade unionism's presence and combativeness in the years immediately following World War II. As a 1947 union flyer stated, "the entire character of the textile community" had changed, and Minchin is well aware of what a "worthwhile achievement" that was (p. 209).

This study's uniqueness lies in its rich evidence. Minchin premises his book on an overview of developments, but he uses case studies of particular locales to provide convincing detail. He is attentive to large structural generalities, and explores these in chapters outlining the history of mill worker unionism and the textile industry before 1945 , the importance of Operation Dixie in the 1946-1953 years, the problem of rising wages in southern textile mills and the ways in which the industry's prosperity in this period allowed employers to deflect workers from unions by simply offering them wage packets equivalent to those earned elsewhere in bitter strikes and costly mobilizations. He presents a short chapter on the 1951 strike across the South, but his focus is on the rich evidence accumulated out of the Danville experience of defeat, a negative record that he balances with a sense of historic achievement conveyed to him in oral testimonies of mill workers in Rockingham, North Carolina. In all of this Minchin draws upon and blends together company records, union evidence, newspaper accounts, rare diaries of labour organizers, verbatim transcripts of union/ management negotiations, and reports of the mill-owner spies. The result is a rich tapestry of perspectives that Minchin orchestrates and displays with judicious effect.
Squaring off against a powerful corporate interest that was determined to defeat worker unionism, the TWUA faced a set of employers as intransigent as any in America. Capital used violence, armed strikebreakers, ugly racism, and gendered chauvinisms, as well as the carrot of high wages and the stick of the police, the courts, and their jail sentences, evictions from houses, seizures of cars and other goods purchased on credit, and whatever else it could draw on to crush what the owners perceived as an unruly challenge to their right to rule the mills and the towns in which textile production was the economic lifeblood of society. Minchin provides the first sustained look at this clash of class interests, illuminating its development with insightful glimpses into the complexities of both workers and employers, examining facets of the struggle not usually commented on, such as factional battles and personality splits within the union hierarchy. If he is perhaps too cavalierly insistent on the way in which his contribution distinguishes itself from the so-called "new labour history," Minchin has written a book all labour historians will benefit from and appreciate. In posing the question What Do We Need A Union For? in the ironic voice of stereotypical southern mill worker conservatism, Minchin answers the query with the text of a historical past rich in its answer of endorsement of the cause of organized labour. In the process, we are reminded, once again, of the South's centrality in the making of modern America, a narrative of success and failure in which more than one valiant cause has gone down to a defeat that registers acutely the need for future victories.

BRYAN D. PALMER

Queen's University 